\title{
Traditional Institution and Nation Building: The Role of Traditional Rulers in the Maintenance of National Security for Sustainable Development
}

\author{
Joseph I. Igwubor \\ http://dx.doi./org/10.4314/ujah.v21i4.12
}

\begin{abstract}
Nigeria has been faced with many security challenges especially since her return to democracy in 1999. Since 1999, the nation witnessed serious security challenges that has not only threatened her existence as a nation but has defied all solutions for its eradication including the efforts of the security agencies to tackle the problem. This calls for an urgent attention and collaboration of the traditional rulers in checking the rising tide of insecurity in Nigeria. As the rulers of various communities, and the custodian of the people's culture, they have a grip of the people at the grass root and therefore can mobilize the people for action against insecurity in their domain and by extension the nation. The paper is to examine not only the roles of the traditional rulers in the maintenance of security for an effective nation building but also how the institution to be restructured for it to perform better in the maintenance of national security for sustainable development in Nigeria. This demands that the traditional institution be restructured in a way and manner that it will operate optimally in the maintenance of national security.
\end{abstract}

\section{Introduction:}

Nigeria since independence in 1960 has witnessed various political crisis that brought about insecurity, destruction of lives and properties as well as disruption of socio-economic life of the people. However, the crisis assumed a different dimension, becoming more sophisticated, more deadly, more militarized with a wider 
international terrorists connections. The development progressed from activism to agitators that adopted civil disobedience as a means to press for their demands to militancy, with sophisticated military weapons and now on the level of terrorism with weapons of mass destruction and having connections with international terrorist organizations such as the Al Quada, ISIS etc. As Mordi observed on the increased of crisis in Nigeria, he stated that "rather than abate with the dawn of democratic governance, violent agitation in Nigeria, including the Niger Delta reached a new height with separatist or selfdetermination goals. Nigeria became a huge guerrilla jungle and a source of nightmare to her citizens and the international community alike instead of a democratic eldorado, with the May 29, 1999 handover of power by the military president" (163).

As a result of the inability of the political leaders and the elites to tackle the problem of insecurity in Nigeria, there is the need to turn to the traditional rulers for a possible solution to this monster, insecurity. The traditional rulers are traditionally, the head of their ethnic group, clan or community. They hold the highest executive authority in such communities and has been appointed to the position in accordance with the people's culture, custom and tradition. Their office and power has been recognized by the government through the presentation of "staff of office", which is an instrument of power. The traditional rulers having been recognized by the government as the leader of their people, has been playing a great role in the management of the people and their affairs. Therefore, their role in conflict management, resolution and prevention cannot be over emphasized as they manage people in their domain and resolve conflicts in the society in order to ensure that, there is peace and stability. 
Igwubor: Traditional Institution and Nation Building: The Role of Traditional Rulers in the Maintenance of National Security for Sustainable Development

\section{The Role of Traditional Rulers in the Maintenance of National Security for Sustainable Development}

The traditional rulers as the leaders of the people and custodian of the people's culture and tradition are highly respected and revered by the people within and outside their domain. Their words are laws to the people and their advice and opinions on issues are respected and accepted. This is so, because they are seen as intermediaries between the people and the gods and the ancestors, and as such, cannot be disobeyed or disrespected. There is the need therefore, for the government to partner and collaborate with them to resolve National crisis and conflicts that could escalate to the level of terrorism in Nigeria. The terrorists and militants belonged to an ethnic group that has a king. They listen to the traditional rulers because of the respect they have for them. The government need to back and encourage the traditional rulers to talk to their people to shelve violence, just as the government did in the Niger Delta recently through the Pan-Niger Delta Forum (PANDEF) which persuaded the Niger Delta militants to shelve ad suspend all actions of militancy in the region which they did. This created stability and boosted economic activities in the region and increased the wealth of the nation.

The traditional rulers can reach the people involved in terrorism and militancy in Nigeria and call them for dialogue and negotiation. The people have the confidence of the traditional rulers and would always confide in them. The government should empower and encourage the traditional rulers to open up the channel of communication with the people, especially the aggrieved ones to know their grievances and demands. The government would not have the capacity to do so because the people might have lost confidence on them just as Ighoavodha noted, "from the optimism that prevailed in the 1960s to the unease and apprehension of the late 1970s, the mood in contemporary Africa has shifted to one of acute anxieties. Commentators now speak of a 'loss of confidence' and write of a 
struggle of survival" (1). Africans, though has lost confidence on their political leaders as result of corruption, underdevelopment and ineffective leadership, they have an implicit confidence on the traditional rulers. This can be seen on the honour and respect accorded to traditional institutions and rulers in Africa. The traditional rulers can negotiate or initiate the process of negotiation for the government in order to achieve peace for sustainable development in Nigeria.

Traditional rulers promote peace, foster cohesion and contribute to the political system of governance. The aim of Government is to ensure that the people, irrespective of tribe or language live harmoniously in an area. This creates political stability that aids development. It ensured the safety of the people and their properties in an area and also held to attract investors. When there are investors, the economy of an area is stimulated, jobs are created, leading to employment and eradication of youth restiveness. Employment is an anti-dote to crimes, militancy and violent agitations. The traditional rulers in ensuring peaceful co-existence in their domain, ensure that the security of the area is guaranteed. This is a major factor in nation building and national security. As Erezene observed, "no responsible country play with its security" (16). This is so because security is the basic factor in the existence and survival of the society and the nation. Therefore as the traditional rulers promotes peaceful co-existence, peace and security in their domains, they are playing a major role in the promotion of national security which is a factor in national development. There is the need for the government to encourage the traditional rulers in this regard to ensure continuous peace and harmony in the society. The society is dynamic and continues to change from time to time and it need peace and security in all ramifications to sustain the change.

The government adapt to the change by modernizing and changing her policies to meet the realities of modernization and 
globalization. The traditional rulers therefore, remain a major force of stability in moments of change. They can serve as intermediaries to ensure that change occur in an orderly and familiar way. In ensuring this, they display an impressive flexibility, adapting to measures that will help meet the needs of the people in order to ensure that there is peace, stability, progress and development in their area or community. They lead their people to adapt to change by publicly accepting the change in spite of the consequences and challenges.

The government, to maintain an effective leadership and good governance, comes up with policies that will ensure its realization. However, in the recent times, people and communities do rise against such policies. It is the duty of the traditional rulers to help disseminate information on government policies and explain its purpose to the people. This has been the practice from the colonial period. This has to a large extent been neglected by the government in recent times. The government needed the traditional rulers not only to explain her policies to the people, but also, help in implementing such policies so as to avoid frictions and conflicts between the people and government leading to instability. As Smith noted, "he who attempts to remove the stability which chieftaincy provides without first ensuring an even greater stability is courting disaster" (22). Therefore, for any government to come up with a policy, especially on a sensitive national issues without letting in the traditional rules to play a role, either in its dissemination or implementation is courting a great disaster for such a policy. It should be noted that, just as the British could not do without the Chiefs and traditional rulers during the colonial period in implementing her policies, so will Nigeria cannot do without them, as they are major a force against factors of instability, disintegration and social chaos.

Traditional rulers are a major factor in the unity of the nation. They remain a great force in the communities and by extension among their neighbours in ensuring peace and unity of the people 
both in their communities and environs which includes their immediate neighbours. They mediate on conflicts and crisis that arises from time to time, ensuring that amicable resolution of the crises are achieved as soon as such conflicts comes up. In the resolution of conflicts, the traditional rulers ensured that crises are well managed so that normal social systems and instruments of control and limitation described by the term, "management" may operate. The traditional rulers, by the office they occupy, are seen as the intermediary between the people and the gods and their ancestors. In some areas their office is considered "divine and sacrosanct". They are therefore held in high esteem as they remain impartial on issues and in conflict management as they answer to the gods for their actions.

It is in search for impartial arbitrators that the traditional rulers were looked up to, for the adjudication of cases and resolution of conflicts. The traditional rulers have done this in the case of Ife and Modakekeland crisis in which the Oni of Ife led the Yoruba Chiefs and traditional rulers to intervene in the crisis. The traditional rulers have continually intervened in the Niger Delta crisis, trying to find a permanent solution to the militancy which continued to disrupt the nation's economic activities especially the oil and gas sector. In the Northern part of Nigeria, the traditional rulers has been doing their best in the resolution of the Boko Haram crisis that has seen the destruction of more lives and property than any other crisis in that region. And recently they are mediating in the farmers and herders crisis. On the land crisis between Aguleri-Umuleri, Nwunegbo noted the efforts of the traditional rulers in resolving the crisis when he stated that, "in the conflicts between these communities efforts were also made by several neighbouring and affiliate communities, to intervene. This manner of intervention usually takes the form of trying to establish a truce of an understanding on the need by an appeal not to continue in the part of conflict" (514). However, though the efforts of the traditional rulers may not resolve the conflicts totally 
or permanently, they none-the-less remain potent in the resolution of the crisis. They may be palliative that help to bring about restrain on the part of parties involved in the crisis as they are made not to go violent or engage in acts that may hinder the peace process. In this regard, people are restrained from using weapons of any kind as one cannot spill the blood of his brother or kinsman. The traditional rulers in ensuring the unity of the people and their neighbours, continue to ensure that there is peace and stability not only in their domain but also in his immediate neighbour and by extension Nigeria in general. The governor of Kaduna state, ElRufai noted the efforts of the traditional rulers in the resolution of conflict when he stated that "the government will assign constitutional roles to the traditional rulers to oversee the security of lives and property in their respective domains. This is in a bid to address the incessant communal clashes and killing in some part of Kaduna".

The traditional rulers as advisers to the government through the state council of chiefs are partners in progress with the government. The advisory role played by the traditional rulers is very important in nation building as they are grass root leaders. They are nearer to the people as they live among them. Their advice on security matters cannot be over looked as they present to the government first hand information on security issues. In some cases, as a result of the respect and reverence the people have for the traditional rulers, divulge sensitive security information to them because of the implicit confidence they have on them. The traditional rulers on their part rely such information to the government to act upon. The tradition rulers through the representative of the Traditional Council of Chiefs are members of the security council in the state. Through this body they make their contribution on security matters. Such contributions have helped in the maintenance of public order and preservation of peace in Nigeria. 
In recognizing the roles of the traditional rulers in the maintenance of security at the local government areas, the Federal Government in its guidelines for local government reforms, provides for the establishment of police committee at the local Government areas in which the traditional rulers are represented. A section of the guidelines as published by the government printer, Kaduna, stated that "the committee is required to hold regular meetings to consider and make recommendations on all matters concerning the police and preservation of peace in the area". The traditional rulers in the maintenance of security in their areas has setup local vigilante which is made up of able bodied men and local hunters in the area. They are funded by the community and in some cases they are on voluntary mission. These local vigilante, police the locality, checking criminality in the area, preventing acts of lawlessness that could lead to breach of peace and instability. They also provide information to the security agencies on security matters. Through these means, the traditional rulers compliment the efforts of the government and the security agencies in the maintenance of national security to ensure stability, which is a sine qua non to nation building. They need to be encouraged and empowered to continue in this regard for sustainable development in Nigeria.

Traditional rulers are bridge builders that could be used by the government to cement the existing relationship among the various ethnic groups in Nigeria. Akinole observed that "the amalgamation of 1914 could not undo the North-South dichotomy" (4). The coming together of our traditional rulers, especially the first class traditional rulers in the geo-political zones, such as the Sultan of Sokoto, the Emir of Kano, the Oba of Lagos, Oni of Ifa, Alafin of Oyo, Oba of Benin, Obi of Onitsha etc can do the magic and undo the North-South dichotomy. Their personal relationships and coming together with a common voice on national issues will help to reduce tension, hatred and suspicion among the peoples of Nigeria. The voice and opinion of 
the traditional rulers is highly respected by the people because of their position in the society. According to Erezene, "they are the traditional leaders of thought, custodians of wisdom, customs and traditions of the people" (4).Therefore, their coming together and collaboration will help in stabilizing the unity, peace and security of the nation as their words can ether make or mar the nation. The collaboration and partnership of the traditional rulers will guarantee the safety of other ethnic group in their domain. It makes the foreigners feel at home as the king is seen as the father of all. Efeizomor noted the importance of collaboration of the traditional rulers when he commented on the existing relationship between his kingdom, Owa and the Benin Kingdom. Thus, he stated "this catalogue of intimacy has continued to the present day particularly when about twenty percent of the present Owa population now reside in various Benin territory. These Owa People have comfortable settled in the above habitations without molestation, making their economic venture under the giant umbrella of Omo N'Oba N'Edo Uko Akpolokpoloand the good custody of their resident Enogieand Odionwere (169). The collaboration of the traditional rulers can ginger and speed up development of an area. The traditional rulers as the motivator of supply, demand and distribution and the generator of traditional wisdom, collectively can call on the government to establish infrastructures and ventures that can generate employment. They can also call on their subjects to invest at home to create employment for the people. Those who contributed to the development of their community are honoured with chieftaincy titles. The efforts of the entrepreneurs and industrialists galvanized into action by the traditional rulers will bring about economic bless in the area. The benefit of this is enormous as Igbafen noted that "under economic bless, crime and criminality including kidnappings, hostage taking, assassinations, armed robberies, endless strikes and political violence either do not exist or reduced to the barest minimum" (161). This is what every community and nation 
aspires to achieve, for it generates employment for the people, especially the youths.

\section{Factors Militating against Traditional Rulers in the Maintenance of National Security for sustainable development in Nigeria}

The traditional rulers have great roles to play in the maintenance of national security. This has become necessary as the government alone cannot provide the necessary security that will secure lives and property in Nigeria as well as guarantee peace and unity of the nation. However, the role of the traditional rulers in this regard is being hindered by a number of factors which includes but not limited to lack of adequate funding of the traditional institution. The traditional rulers have no security vote or any allocation for security. This hinders their efforts to effectively mobilize the people for action on security matters. The local vigilante they established for the maintenance of security in their domain are not remunerated and all the traditional rulers can do is a tip occasionally.

In the 1999 constitution, there is no definite constitutional role for the traditional rulers. This is one of the defaults of the 1999 constitution. How do they operate without a constitutional backup for their actions? A thorough scrutiny of the Nigerian constitution since 1979 clearly shows that traditional authority has not been recognized therein. It is a known fact that, even if the state council of chiefs/traditional rulers is in the constitution, it's membership is prescribed by the state House of Assembly without a constitutional role and according to Ekong "such council is supposed to act in advisory capacity to the state government, whenever requested to do so" (101). It should be noted that the government may accept or reject their advice.

The power of the traditional rulers in conflict resolution has seriously been undermined both in terms of authority and power. Attesting to this fact, Abdulqadir noted that "the instruments of 
Igwubor: Traditional Institution and Nation Building: The Role of Traditional Rulers in the Maintenance of National Security for Sustainable Development

coercion the police, courts, prisons, were removed from its control"(8). There is no constitutional provision for the enforcement of the resolution reached in arbitration. Alagoa shared a similar view when he stated that, "the traditional institutions no longer have full rein of operation, since they have to operate in a context where there authority is limited by Federal, State and even Local Government authority" (31). Without the means of enforcing the decisions reached in the arbitration, the parties in conflicts may refuse to abide by the terms reached.

Also, as Nwani noted, "the emergence of public court destroyed the use of our traditional conflict resolution mechanism because it encourage people to bypass traditional courts to go regular courts"(213). In some cases, the traditional rulers neglect their primary role as conflict managers especially at the grass root. Their inability to intervene at the earlier stage of crisis has led to the escalation of such crisis leading to a serious instability, chaos and huge damage to lives, property and economic activity of the nation.

\section{The Way Forward for a Restructured Traditional Institution}

The traditional rulers have a great rule to play in the maintenance of security for a sustainable development in Nigeria. However, for the traditional rulers to play the role effectively, they should be security allocation for the traditional institution which will enable the institution to mobilize the people for the maintenance of security. The government should give the traditional institution constitutional recognition and backing for their actions. This will enable the decisions reached in arbitrations by traditional rulers implemented by parties in conflicts. In a restructure Nigeria, the traditional rulers should be partnered by the government and security agencies to obtain information on security matters in an area. Such information should be treated with up uttermost secrecy and with dispatch. The traditional rulers should be allowed and encouraged to establish 
security council or committee in their domain with the collaboration with security agencies. Their area of focus can be set out by the government. When this is done, security will be better handled both by the government and the traditional rulers who are at the grassroots as the government cannot handle security alone as events of the recent time has shown.

\title{
Conclusion
}

It has been pointed out that the traditional rulers have a role to play in the maintenance of security in Nigeria. This is due to the fact that the government cannot do it alone. Also, the fact remains that the traditional rulers are grassroot leaders who live among the people. They are highly respected and revered as the custodian of the people's culture, tradition and wisdom. As grass root leaders, they have a grip of the security of the area and the people can confide in them on security matters. They are therefore in a better position to play a role in the maintenance of security in Nigeria.

\author{
Joseph I. Igwubor \\ Department of History \\ College of Education, Agbor \\ Delta State, Nigeria
}

\section{References}

Abdulqadir, U.A. Traditional Rulers and Security administration in Nigeria: Challenge for the $21^{\text {st }}$ Century. Journal of Humanities and social sciences vol. 21:8. 2016.

Akinola, G.A. "Leadership and the post colonial Nigerian Predicament" Monograph SeriesNo.1.Ibadan School of History.2009

Alagoa, E.I. "Conflict Management: Traditional models from the Nigerian South-South Zone". Nigerian Heritage: Journal of 
Igwubor: Traditional Institution and Nation Building: The Role of Traditional Rulers in the Maintenance of National Security for Sustainable Development

the National Commission for museums and monument Vol. 10. 2001

Efeizomor E. Community Development in Owa Kingdom-The Nigerian Factor. Benin: University of Benin press.1994.

Ekong, E. Ekong"Traditional Rulership in contemporary Nigeria government system and the Delemma of Relevance" in Aborisade (ed) Local Government and the Traditional Rulers in Nigeria. Ife: University of Ife Press.1985

Erezene, H.B A history of the Iduwini and Kou in the Western Niger Delta. Agbor: Progress Printing Associates, 2010.

Erezene H.B. "Continued crises in the Niger Delta: Implications for National Security and Resource Management in Nigeria in Babatolu and Gbade. I (eds) National security and resource management in Nigeria. Ondo: Alafas Nigeria company.2011

Federal Republic of Nigeria, Guidelines for Local government reform, Kaduna: (The government printer) n.d; p. 15

Igbafen M.L. The challenges of leadership and development in Africa: Theory and Praxis Selected Essays of JuliusO.Ihonvbere. Ibadan: Book Wright publishers. 2012 Ighoavodha F.J.O. The Quest for political stability in Africa: Nigeria's post colonial Experience. Lagos: O.O.P Limited.2002

Mordi, E.N. The return of democracy and escalating violence in Nigeria, 1999-2004: A Historical Analysis in Orbu C.O et al (eds) Nigeria: The challenge of Democracy and Development in the twenty-first century. Benin City:Ethiopepublishing corporation 2005

Nasir, El-Rufai. June 16,2016, Channels television:

Nwanegbo, C.J Inter-communal conflict in the South-Eastern Nigeria:

A study of Aguleri-Umuleri conflicts in Ikejiana-Clerk M.M.(ed) Peace studies and conflict Resolution in Nigeria. Ibadan: spectrum Books. 2009 
Nwani, U.Umunede Kingdom:Changing Aspects of its Culture and Customs. Agbor: Central Bookshop.2011

Smith, J. The relationship of the British political officer to his Chiefs in Northern Nigeria in Crowder M. and Obarolkime (eds) West African Chiefs. Their changing status under colonial Rule and independence. New York: African publishing corporation. 1970 